\title{
Monetary Policy and Economic Performance: the Recent Experience of the United States and Japan
}

\author{
Kumiharu Shigehara*
}

\section{Introduction}

The recent fine record of United States monetary policy has often been contrasted with unsatisfactory performance elsewhere, ${ }^{1}$ including in Japan. In particular, the United States economy avoided severe overheating in the late 1980s and the subsequent recession was shallow and followed by a sustained and robust recovery with low inflation. By contrast, monetary policy arguably contributed to the "bubble" economy in Japan in the late 1980s, and since the early 1990s the Japanese economic growth has been very weak. The United States economy is now at or slightly above the previously estimated level of potential output with no signs of rising inflation, while the Japanese economy is performing well below potential. It must be said, of course, that the picture is not all onesided: since the early 1980s, Japan has enjoyed both higher growth and lower inflation than the United States on average (Figure 1).

This paper examines the extent to which the evolution of monetary policy frameworks and actual policy decisions in the United States and Japan have contributed to the differences in macroeconomic performance of the two countries in the 1980s and 1990s. It considers the extent to which monetary policy decision-making was faulty and how it might have done better, given the information available to policy-makers at the time. The discussion also provides some insights into the contributions of academic thinking to monetary policy-making, based in part on my own experience as a central banker and a policy adviser in an international organisation engaged in international economic policy co-operation.

\footnotetext{
* Deputy Secretary-General of the Organisation for Economic Co-operation and Development. This paper was presented to a "Central Bankers' Panel" at the International Economic Association's conference "Monetary Theory as a Basis for Monetary Policy", 4-7 September 1997, Trento, Italy. Valuable contributions from Charles Pigott are acknowledged. The views expressed herein are those of the author and do not necessarily represent the official views of the Organisation, where the author was Chief Economist and Head of Economics Department from May 1992 to May 1997, nor those of the Bank of Japan where the author served as Director-General of the Institute for Monetary and Economic Studies between December 1989 
In brief, the paper concludes that monetary policy frameworks did not differ in most respects between the United States and Japan over this period and that, with one important exception, the differences in policy frameworks that did exist do not explain the differences in macroeconomic performance. The exception is that, under the current law, the Bank of Japan is less independent from the government than the Federal Reserve. This constraint, coupled with some errors of judgement, impeded the proper decision-making of monetary policy in Japan at a critical juncture during this period. The paper points out that Japanese monetary policy was too loose leading up to the bubble economy in the latter half of the 1980s, and, despite political resistance and other difficulties, policy makers should have tightened financial conditions earlier than they actually did to correct the imbalances that were building up. It is also argued in the paper that monetary policy in Japan should have been eased more aggressively in the early stages of the recession in the 1990s, although it would have been difficult for policy makers at the time, with the history of the bubble fresh in their minds, to formulate and justify bold action. On the other hand, the paper concludes that U.S. monetary policy was, in fact, generally well executed during this period, but it had some help at times from fortuitous movements in asset prices. Thus, the paper acknowledges that there are pitfalls in an "eclectic" approach to monetary policy, but it also notes that there were reasons why neither the Federal Reserve nor the Bank of Japan could follow a simple rules-based strategy as advocated by some academics. At the same time, it is pointed out that monetarism -- which I understand as arguing that there is no longrun inflation-output tradeoff, that money matters for inflation and that the ultimate goal of monetary policy must be price stability -- has carried the day in the intellectual and practical debates about monetary policy. This is fortunate, since it has undoubtedly helped to improve monetary policy over the past couple of decades.

\section{Evolution of Monetary Policy Frameworks}

In this section, I shall review how monetary policy frameworks and objectives have evolved in the United States and Japan during the period from the mid-1980s to present, in comparison with those practised in the earlier decade since the mid-1970s. 
In a paper presented to the Bank of Japan's first international conference in 1983, Milton Friedman (1985, p. 27) wrote that "my impression is that Japan illustrates a policy that is less monetarist in rhetoric than the policies followed by the United States and Great Britain, but far more monetarist in practice. In any event, since the change in policy in 1973, when inflation reached 25 per cent and monetary growth was over 25 per cent, Japan has followed a fairly consistent policy of holding down the rate of monetary growth and keeping it relatively steady -- and the result has been that Japan has been less affected by economic instability than the other two countries". This international conference brought together Milton Friedman and James Tobin, the then two Honorary Advisors to the Bank of Japan's Institute for Monetary and Economic Studies, and other leading academic experts in Japan and abroad, as well as central bank senior economists from western countries belonging to the Group of Ten and several countries in the Asia-Pacific region.

Friedman's characterization of the Bank of Japan as monetarist in practice needs to be subjected to careful analysis in at least two respects. The first issue relates to the relationships between money, nominal income and inflation in Japan. These were more stable during the period from the mid-1970s to the mid-1980s than during the earlier decade (Figure 2), as demonstrated by Suzuki (1984). However, it is not clear whether the direction of causality ran from money to real output and prices. Granger-type causality tests could not establish firm conclusions in this respect. The second issue is whether the Bank of Japan's monetary policy was rules-based in the monetarist sense in practice, if not in rhetoric. In July 1978, the Bank of Japan started publishing forecasts on the growth rate of broad money (M2; later M2 + CDs). While some economists argued for the introduction of monetary targets in the monetarist sense, most policy advisers within the Bank of Japan, including myself, were cautious about the introduction of strictly target-oriented monetary management. While several econometric tests showed that the demand for money was fairly stable in Japan, even relative to some of the countries which had introduced strict monetary targeting, policymakers and most senior advisers at the Bank of Japan were concerned that failure to achieve targets might distort market expectations about the central bank's future course of action and undermine the credibility of monetary policy (Shigehara, 1990). We took the view that the credibility of monetary policy ultimately depends on inflation track records rather than success in controlling intermediate variables such as monetary aggregates. However, by announcing monetary projections, the Bank of Japan elevated the status of money supply to a crucial indicator. At the same time, the Bank made it 
clear that the stance of monetary policy should not be dominated by developments in monetary aggregates especially over the shorter term.

In contrast to Friedman, Hamada and Hayashi, who also presented a paper to the first international conference of the Bank of Japan, observed that an important reason for the smooth conduct of monetary policy in Japan during the period they examined (the 1970s and the early 1980s) was that the Bank of Japan aimed at not immediate but medium-run control of broad money and did not pay too much attention to narrow money, which often exhibits erratic movements. They noted that "the Bank pays sufficient attention to other indicators than a single monetary aggregate. The Bank watches levels of interest rates, particularly the call market rate, price indices, liquidity conditions of firms, the retail-sales index, the general business outlook, and, recently in particular, the value of yen exchange rates. It is perhaps appropriate to say that monetary policy in Japan has been successful because the perspective of the Bank is multi-scoped rather than single-scoped on a single aggregate" (Hamada and Hayashi, 1985, p. 99).

This basic framework for monetary policy operating procedures in Japan has remained unchanged during the recent decade. Around the beginning of the 1990s, some internal debate occurred within the Bank of Japan on whether the practice of announcing projections of monetary aggregates should be abandoned in view of the growing instability of money demand associated largely with on-going financial liberalization (Figure 2). As the Bank of Japan's practice had been to publish, at the beginning of each quarter a projection of the growth rate of broad money for the four quarters ending at the end of that quarter, it had the benefit of describing monetary developments that had mostly already occurred. Nevertheless, the divergence of monetary outcomes from projections tended to widen in the late 1980s, raising questions about the usefulness of publishing monetary aggregate projections. In the end, the Bank decided not to abandon the practice, as it was considered useful in forcing the Bank to assess the relationship between the money supply -- a key nominal variable for monetary policy -- and output and inflation, and to evaluate the policy implications of divergence of monetary outcomes from projections on a regular basis.

While the acceleration of financial liberalization in Japan since the mid-1980s contributed to increased instability in the demand for money, it also influenced the Bank of Japan's choice of monetary policy instruments. In response to new developments in domestic money and capital markets, the Bank of Japan started to rely increasingly on open market operations, using a variety of securities and other paper. It also decided to rely no longer on quantitative guidelines on bank lending 
in periods of restraint. In this sense, the conduct of monetary policy in Japan has become closer to the U.S. system, with the primary operating target of the Bank of Japan continuing to be short-term money market conditions.

The evolution of U.S. monetary policy operating procedures, in particular with regard to monetarist approaches, has been similar in many respects to that of Japan. The Federal Reserve began to formulate target ranges for several monetary aggregates beginning in the mid-1970s and, subsequently, under the Full Employment and Balanced Growth Act of 1978 ("Humphrey-Hawkins" Act), was required to report on these targets to the U.S. Congress. However, these ranges were not used as formal intermediate targets in any strict sense until October 1979, when Chairman Volker initiated rigorous short-term monetary targeting in order to facilitate the authorities' efforts to reduce inflation. As is well known, this strategy focused on non-borrowed bank reserves as an operating variable for controlling monetary aggregates as intermediate targets, which resulted in greater variability of short-term money market interest rates. The strategy was also fairly short-lived, as the Federal Reserve ended its strict adherence to short-term monetary targeting in August 1982, by which time evidence about the recession and disinflation in the United States had become abundantly clear. Milton Friedman was therefore correct in insisting, at the Bank of Japan conference referred to above which took place less than one year after departure from the new strategy, that "the rhetoric of the (U.S.) monetary authorities has been monetarist, but their policies have not been -- or, to be generous, have been only partly so" (Friedman, 1985, p. 15).

Since August 1982, the Federal Reserve has continued to pay attention to monetary aggregates, but their role as a target has gradually disappeared and even their role as a policy indicator has progressively declined. The evolution of U.S. monetary policy operating procedures during the recent decade is well described in Benjamin Friedman's paper (1997) presented to the seventh international conference of the Bank of Japan in 1995. In 1987, the Federal Reserve discontinued the practice of setting a target for the narrow money stock. While target ranges for wider measures of money were maintained in the subsequent years, in 1993, the Federal Reserve made it clear that it had "downgraded" even broader monetary growth targets. In a paper presented to the 1993 Conference sponsored by the Federal Reserve Bank of Kansas City, Benjamin Friedman (1993) argued that in the light of developments in the U.S. financial system which added to the instability of the demand for various measures of money, the Federal Reserve must look at all types of incoming information. In commenting on that paper at the conference, Donald Kohn, Director at the Federal Reserve Board, noted that "this certainly has been the practice of the Federal Reserve for most of its history, including 
the fall of 1982. Throughout this most recent period, monetary aggregates, including M2, have played a role in policy, but as information variables rather than as targets. And that role has been reduced as atypical velocity behaviour called into question the information content of first one aggregate and then another. Quite frankly, I don't see an alternative to the current inclusive, intensive procedure" (Kohn, 1993, p. 198).

This short description of the evolution of monetary policy operating procedures in the United States and Japan suggests broad similarity in key aspects of their policy frameworks. Thus there is little in this area which can explain the differences in macroeconomic performance of the two countries during the recent decade. I shall turn to the question of whether there have been differences in the choice of ultimate targets of monetary policy, de jure or de facto, between the two countries.

\section{Choice of ultimate targets: Is there a difference between the United States and Japan?}

The inflation and unemployment experiences in OECD countries during the 1970s demonstrated to the satisfaction of almost all analysts that the Phillips curve is vertical in the long run and that monetary policy can therefore affect only inflation in the long term -- a view which had been pioneered by Milton Friedman (1968) and Edmond Phelps (1968). The view is now widely shared that the primary goal of monetary policy should be price stability over time. And in public debate, price stability and a small but positive rate of inflation in terms of the consumer price index are often used interchangeably, partly in view of measurement biases in price indices that lead them to overstate somewhat the true inflation rate.

In recent years, a number of OECD countries have adopted numerical inflation targeting. They are generally countries with a historical record of relatively high inflation, and inflation targeting was introduced both as a means of communicating the goal of monetary policy to the general public, and as a guide to assessing central bank performance -- see Shigehara, 1996(a). Neither the Federal Reserve nor the Bank of Japan have announced their numerical inflation targets. While the rhetoric of many central bankers has been that price stability is the only goal of monetary policy, a number of central banks, including the Federal Reserve and the Bank of Japan, are actually governed by charters that charge them with promoting price stability along with real economic growth, and in some cases, other goals. The U.S. "Humphrey-Hawkins" Act Section 2A defines the objectives of the Federal Reserve as the maintenance of "long run growth of the monetary and credit aggregates commensurate with the economy's long run potential to increase production, so as to promote effectively the goals of 
maximum employment, stable prices, and moderate long-term interest rates". The current Bank of Japan Law, introduced during the Second World War and only partially revised in the immediate postwar period, sets even broader objectives of "regulation of the currency, the control and facilitation of credit and finance, and the maintenance and fostering of the credit system, pursuant to the national policy, in order that the general economic activities of the nation might be adequately enhanced"(Suzuki, 1987, p. 305). Neither of the legal settings thus explicitly establishes price stability as the prime, let alone exclusive, long-term objective of the central bank. In any case, aside from legal matters, most practising macroeconomists believe that judicious use of monetary policy can, and should, be used to reduce short-term economic fluctuations, although always in the context of medium-term price stability.

During the Bretton Woods period, the fixed dollar exchange rate regime coupled with low inflation in the United States until the late 1960s provided an anchor for monetary policy in nonreserve currency countries including Japan. During this period, capital movements were tightly controlled, and trade and current account equilibrium through maintenance of stable prices for traded goods ensured the dollar exchange rate stability. Given considerably faster productivity growth in traded goods sectors than in services and housing in Japan during this period, pursuit of stable prices for traded goods meant fairly significant inflation for consumer prices (see Figure 1, Panels IIIA and B). With the end of Japan's high growth period during the 1970s, productivity growth divergence between the traded manufactured goods sectors and services and housing sectors narrowed and consumer price inflation as well as producer price inflation has been contained within a very low range since the mid-1970s.

The departure from a rules-based system of the fixed dollar exchange rate has not meant that monetary policy has been freed completely from exchange rate considerations. Although in theory the asymmetry between the United States as the primary reserve currency country and non-reserve currency countries disappeared as a result of a generalised shift to the floating exchange rate regime in the OECD area in 1973, some element of asymmetry has remained: as many countries outside the OECD area have endeavoured to orient exchange rate policies towards maintaining stability against the U.S. dollar, changes in the dollar's bilateral exchange rates vis-à-vis currencies of other OECD countries could have resulted in greater swings in their trade-weighted effective exchange rates than those produced in the effective exchange rate of the dollar. The responses of the monetary authorities in non-US OECD countries to the new situation have varied over time and among them. European countries with growing intra-European trade integration (Table 2) introduced the regional 
arrangements limiting exchange rate fluctuations between their currencies, culminating in the European Exchange Rate Mechanism (ERM). This has helped to prevent large swings in their tradeweighted effective exchange rates (Figure 3). Most countries participating in the ERM are now planning to introduce a common currency called the "euro". Without such currency arrangements in the Asian Pacific region, the evolution of the dollar exchange rate vis-à-vis the Japanese yen has had a significant influence on the yen's effective exchange rate, and has therefore loomed larger in economic policy conduct in Japan than in Europe. Even for the United States, large swings in the dollar effective exchange rate occurred in the 1980s despite the dollar-pegged system in use in many nonOECD economies. They appear to have at times affected at least the timing of monetary policy adjustments, although the "trade openness" of the United States measured as the ratios of exports and imports to GDP has been fairly limited (more on this below).

Concern about the destabilising demand effect of large fluctuations in the exchange rate does not necessarily mean that the primary objective of monetary policy -- price stability -- should be subordinated to the objective of maintaining exchange rate stability. In theory, monetary policy can respond to exchange rate changes without compromising the objective of price stability to the extent that the authorities can measure the effects of exchange rate changes on output and prices and offset them with interest rate adjustment. In reality, the authorities do not know these effects precisely and have at times committed serious policy errors. Such errors are more likely to happen when the central bank is not independent in policy-making and is subjected to pressure from politicians who, often because of their political agenda, want to exploit the short-run trade-off between inflation and output to attain a higher level of output than is sustainable in the longer run. A typical example is found in the conduct of Japanese monetary policy after the revaluation of the yen under the Smithsonian agreement in 1971. Nakagawa (1981), then Executive Director of the Bank of Japan acknowledged that, in retrospect, the Bank overestimated the deflationary impact of the yen revaluation. Moreover, he revealed that the Bank of Japan's monetary policy tightening had been delayed partly because of pressure from the then Prime Minister Tanaka against such a move. Political pressure continued into early 1973 , by which time inflation had risen to double-digits.

In the United States, the independence of the Federal Reserve, along with the predominent position of the U.S. Treasury in the formulation of U.S. external economic policy, has largely insulated the central bank from serious conflicts between exchange rate and monetary policy objectives and the dollar exchange rate has not been used as any meaningful target of monetary policy (Prell, 1991; Pauls, 1991). However this does not mean that the Federal Reserve has ignored 
movements in the dollar exchange rate in formulating policy. The U.S. monetary authorities have used, and continue to use, the dollar exchange rate as an information variable in assessing future economic conditions bearing on monetary policy decisions (Prell, 1991). This use reflects the fact that dollar exchange rate movements have significant effects on the U.S. economy: according to a fairly typical set of estimates, a half to one percentage point cut in the real short-term interest rate is required to offset the negative aggregate demand effect of an exogenous appreciation of 10 per cent in the real effective exchange rate of the dollar. Concerns over foreign exchange market conditions also have played a role in monetary policy deliberations and decisions in certain instances, notably in the aftermath of the severe downward pressures on the dollar in November 1978 and October 1979 and at certain points in 1985 and 1986 when foreign exchange market conditions were placed first among the economic factors cited in the operating directive as the basis for decisions on policy adjustments that could be undertaken between meetings of the Federal Open Market Committee. ${ }^{2}$ Foreign exchange market conditions seem to have mainly affected the near-term timing and manner of decisions that probably would have been undertaken based on domestic considerations in any case.

However, U.S. monetary policy has not necessarily been completely immune from political pressure associated with exchange rate considerations. Poole argued that the outcome of the 1985 Plaza agreement of the Group of Five Finance Ministers and Central Bank Governors to manage the exchange rate was mismanagement of domestic monetary policy. His judgment was that the Plaza agreement led to a situation in which U.S. monetary policy was too expansionary for too long in 198586, by providing "an international stamp of approval on U.S. policies to achieve that result [dollar depreciation]" and "to prevent the Federal Reserve from reacting to depreciation by tightening monetary policy" (Poole, 1990, pp. 59, 63). Nevertheless, I would add that, unlike the earlier period, the Federal Reserve did not wait for unequivocal signs that inflation was actually rising before taking the first step to tighten monetary policy: the first tightening action in 1987 came as the economy was at or near full employment, as the downtrend in underlying inflation was fairly clearly starting to abate, and as the pressures from rising commodity prices and from the dollar's depreciation were showing up in posted inflation numbers. ${ }^{3}$

The Plaza package deal involved not only the dollar's depreciation (and later at Louvre, its stabilization) but also the promotion of more expansionary monetary and fiscal policies in Japan and Europe. In this context, the orientation of monetary policy in Japan was particularly problematic. Monetary expansion there started to accelerate in early 1986 in the face of the deflationary demand effects of the yen's sharp appreciation (Figure 3) and fiscal contraction (Figure 4). The discount rate 
was cut five times from 5.0 per cent to reach a post-war low of 2.5 per cent in February 1987 (Figure 5). Many observers including Ueda (1993) share the view that monetary easing in 1986 to offset the disinflationary effect of a sharp decline in net exports associated with the yen appreciation was probably appropriate. On the other hand, the final cut in Japan's discount rate in February 1987 appears to have contributed to an unprecedented cycle of stock and real estate prices which had a significant destabilizing role on economic activity in the subsequent years -- an issue I shall review in the following section. Arguing against discretion, Meltzer noted that "Japanese policy-makers in the second half of the 1980s changed from a credible policy of maintaining low inflation to an exchange rate target at a time of deregulation. The new policy financed the so-called bubble economy. The monetary base increased at a compound rate of 11.5 per cent for the three years 1986-89. This was nearly double the growth rate of the previous three years. The stock of base money increased more than 38 per cent in these three years. By 1991, the monetary base growth went into asset markets in anticipation of higher inflation. When money growth fell, anticipations changed to disinflation or deflation, and asset prices collapsed" (Meltzer, 1993, p. 216-217).

As an economic policy advisor at the OECD involved in the process of international cooperation, I periodically expressed doubt about the orientation of monetary policy in Japan at that time, but, in retrospect, perhaps, not strongly enough. Having said this, I must point out that the conduct of monetary policy during period was particularly difficult both technically and politically. Pressure from both domestic and foreign sources were put on the Bank of Japan to contribute to exchange rate stability and to promote domestic demand led growth with the view to achieving a substantial reduction in Japan's current account surplus which had grown against the background of a combination of expansionary fiscal policy in the United States and fiscal consolidation in Japan during most of the 1980s. A very low inflation rate prevailing throughout this period, rising only very gradually from 0.1 per cent (in terms of the GDP deflator) in 1987 to 2.7 per cent in 1991, made it particularly difficult for the Bank to resist such pressure. I would guess that if the Bank of Japan had been a more independent central bank, the course of monetary policy in the latter half of the 1980s would probably have been different. In some contrast, the Federal Reserve, considered to be more independent (Keech and Morris, 1997), revised its monetary policy stance already in 1987 to prevent the earlier monetary ease from bringing about a significant rise in inflation. Even so, U.S. inflation reached a peak of 4.3 per cent (in terms of the GDP deflator) in 1990, much higher than Japan's peak inflation rate of 2.7 per cent in the subsequent year (Figure 6). On this account, it would appear difficult to blame the Bank of Japan for any major portion of the macroeconomic problems that 
developed in the Japanese economy beginning in the late 1980s. A more detailed account of its role in economic stabilisation will be provided in the following section.

\section{Causes of Economic Instability and the Stabilisation Role of Monetary Policy}

The Japanese business cycle since the mid-1980s has been unusually long and deep. The upswing leading to the "bubble" started in December 1986 and continued for 51 months. During this phase, business fixed investment as a ratio to GDP reached a 20 per cent level, exceeding the earlier peak during the post-war high-growth period. The subsequent recession which began in March 1991 continued for 32 months, more than double the average length of downswings in the previous business cycles, and the recovery, since the trough that was reached in October 1993, has so far remained sluggish. By contrast, the United States experienced a relatively shallow recession in 1990 followed by a robust, though initially hesitant, and prolonged upswing.

In this section, I shall examine various causes for the differences in cyclical patterns experienced by the U.S. and Japan over the recent decades, and what monetary policy should or could have done to reduce economic fluctuations without compromising the objective of price stability.

Table 1 shows the volatility of various demand components in the United States and Japan for the two periods: 1972-1984 and 1985-1996. In the United States, the volatility of all major demand components declined during the more recent period. In Japan, private consumption, which is not very sensitive to changes in financial conditions, has become less volatile during the recent decade. However, business fixed investment, which is the second most important demand component and is sensitive to financial impulses, has increased in volatility. Housing investment, whose sensitivity to changes in financial conditions has been increasing, has remained as volatile as in the previous period.

These observations raise important questions about the contribution of changes to financial and real asset market conditions, such as equities and real estate prices, to aggregate economic activity, and the role of monetary policy in offsetting the destabilizing economic effects of large swings in asset market prices. These issues will be examined first in the context of the asset market booms in the second half of the 1980s, and then in relation to the balance-sheet problems and asset price fluctuations in the 1990s.

Implications of asset market booms in the second half of the 1980s 
In the United States, there were regional real estate price booms and busts, particularly in the commercial sector, but there was nothing approaching a nation-wide phenomenon. While debt accumulation by households temporarily "overshot" somewhat by the end of the 1980s, the accumulation was part of a "financial deepening" arising from financial innovations that was accompanied by an equally dramatic increase in financial assets -- a process that has proved to be largely longer lasting. Household financial problems, in conjunction with the balance-sheet problems of banks, appear to have weakened the early stage of the recovery in the United States (see Greenspan, 1992; OECD, 1992; Akhtar, 1993-4), but, overall, their effects were less severe and more quickly alleviated than in some other countries such as the United Kingdom and Nordic countries.

In Japan, history since the early 1990s has confirmed earlier suspicions that the marked booms in domestic equities (Figure 7) and real estate markets (Figure 8) during the latter half of the 1980s were driven, at least in the later stages, by speculative "bubbles" that were bound to collapse. Obvious questions are how far the expansionary monetary policy that was in place in the late 1980s instigated or encouraged these bubbles, and whether a judgement to tighten monetary policy earlier could reasonably have been based on information known at that time. During the real estate boom period of the early 1970s, signals provided by financial markets and the real economy were clearly indicating that monetary policy was overly expansionary: monetary expansion accelerated sharply; domestic wages began accelerating even before rises in the prices of oil and other commodities; real estate prices were a nation-wide phenomenon. In contrast, during the latter half of the 1980s, overall inflation remained low, not just because of the appreciation of the yen or the fall in world oil prices beginning in 1985. Even after the direct effects of these changes had worn off, certainly by 1989, core inflation remained barely above 2 per cent and there was little sign of any serious acceleration in wage pressures. Moreover, until fairly late in the 1980s, land price booms were confined largely to the commercial areas of Tokyo where the demand for office buildings increased substantially in the context of growing internationalisation of the Tokyo business centre, and they never proved to be a nation-wide boom as during the early 1970s. Likewise, the boom in capital spending and housing seemed at least partly explainable at the time as the upswing portion of a "long" investment cycle.

During the late 1980s, the causes of the very high equities prices and, associated with them, the relatively low cost of capital in Japan were a subject of a number of studies by both academic and non-academic experts in Japan and abroad. Unfortunately, the result of such studies remained inconclusive. There were (and are) plausible reasons for believing that stock price movements were 
not monetary phenomena (see, for example, Hutchison, 1994). As the current debate in the United States illustrates, given the range of reasonable estimates of future earnings growth, equity risk premia and other determining factors, it was, and still is, very difficult to determine at what point stock prices become unsustainable. ${ }^{4}$ A similar observation can be made about the efforts to determine the equilibrium level of land prices and the point at which they become unsustainable. In a seminal paper, Alchian and Klein (1975) argued that the prices of both current and future goods and services should be incorporated in a correct measure of inflation, and considered for inclusion of asset prices which are thought to embody the relative price of future goods and services. However, given the overall economic situation prevailing in Japan in the second half of the 1980s, as described above, targeting a measure of inflation including asset prices, could have caused large offsetting variations in the prices of current goods and services, and in output activity, depending on the weight to be attached to asset prices.

Despite the inherent ambiguity in various market signals, it appears justified to argue that Japanese monetary policy should have been tightened earlier during the second half of the 1980s, based on information then available. An important question in this regard is how far such an action could have contributed to economic stabilization. Yoshikawa and Ohara (1997) looked into this issue using a simulation model. The result of their exercise suggests that if monetary policy had been tightened a year and a half earlier than was actually the case (in late 1987 instead of May 1989), the business fixed investment cycle could have been smoothed by reducing the annual growth rate of investment during 1988-89 by 3-5 percentage points. This would have sustained double-digit growth rates for investment for three more years, or into the third quarter of 1991. But, thereafter, investment would have dropped to the actual level. Their conclusion is that business investment booms and busts, the most important factor for aggregate demand fluctuations during the recent decade in Japan, were caused by autonomous growth optimism, and the role of monetary policy was minor. Ueda (1995) reached a similar conclusion using structural VAR analysis: that monetary policy actions based on the McCallum approach (using the monetary base for nominal income growth targeting) could have reduced the boom-bust cycle at best modestly. Moreover, Yoshikawa and Ohara argued that, given the overall price situation, the Bank of Japan could not have tightened monetary policy for the sake of pursuing the ultimate objective of price stability; it could have embarked on earlier monetary tightening only for the sake of using monetary policy as an instrument of smoothing fluctuations in economic activity.

\section{Banking sector problems and asset price fluctuations during the 1990s}


During the 1990s, banking sector problems influenced both macroeconomic performance and the conduct of monetary policy to a differing degree in the United States and Japan. In the United States, the second savings and loan crisis of the late 1980s had little or no impact on macroeconomic performance (though it was costly to the fiscal authorities). By contrast, the problem loans, mainly for commercial real estate, experienced by commercial banks during the early 1990s, did have perceptible macroeconomic consequences. A marked slowdown in bank lending occurred, and the balance of evidence suggests that the weakened conditions of the banks was a contributing factor, although it was not considered to be a major factor. The reduction in overall credit supply contributed to weakness in construction and possibly consumer durables spending during the early recovery; but again, it was not a main factor contributing to the hesitancy of the early recovery which appeared to be attributable largely to the balance sheet problems of the enterprise and household sectors, with consequent weakness in demand for funds (for a review of evidence on these issues, see Akhtar, 1993-4). The relatively developed and flexible financial markets in the United States provide an alternative to bank financing, which remains the major channel of credit flows in Japan and most European countries. Once interest rates were reduced to sufficiently low levels ${ }^{5}$ and the demand for funds revived, these alternative sources of financing worked to alleviate the real economic impact of the banking sector problems.

Banking sector problems in Japan have been much more severe and protracted than in the United States. Although the proximate result of the bubble, they represent deep-rooted structural problems in the financial sector itself, resulting from competitive distortions associated with the slow process of deregulation that induced banks to take on excessive risks relative to potential returns. The problems were compounded by flaws in banks' internal risk management system and serious inadequacies in the supervisory and regulatory apparatus. Banks' balance-sheet adjustment has clearly restrained credit availability, in particular to small and medium-sized business firms. Bank loan rates have fallen noticeably less than policy interest rates or short-term market interest rates (Figure 9). The consequent rise in loan spreads, together with zero or slightly negative inflation and a zero floor on nominal interest rates, prevented real short-term interest rates from becoming zero or negative as observed in the United States in its early phase of economic recovery (Figures 5 and 6). Moreover, the less developed state of capital markets has provided few alternatives to bank financing for less wellestablished business firms, even where the demand for finance existed. 
If it is fairly clear that long-standing distortions in the Japanese financial system are substantially responsible for the exceptional severity of its banking system problems and a prolonged hesitant recovery phase of the economy, it is much harder to enumerate the causes for the marked contrast between the character of the currency and bond market fluctuations that hit the two countries during much of this decade. The U.S. experience suggests the proposition that liberalised financial markets tend to be stabilizing, but Japan's experience has sometimes been quite the contrary. In explaining this difference, it is difficult to avoid the role of coincidence, or "luck". For example, the 1994 runup in long-term bond yields in the United States (Figure 10) reinforced the stabilising effect of the monetary tightening and helped to produce a soft landing of the economy from unsustainably high growth in that year; but in Japan, as well as in Europe, the concomitant increases in long-term interest rates in 1994 contributed to a delay in their economic recoveries in the subsequent years (for further discussion, see OECD, 1996). Equally, the misalignment of exchange rates, which drove the yen to a record high of 80 yen to the dollar in the spring of 1995, added a strong deflationary impulse to the Japanese economy (Figure 3). On the other hand, the real effective exchange rate of the U.S. dollar remained fairly stable throughout this period, as the U.S. dollar's depreciation against other major OECD currencies was largely offset by its appreciation against the Mexican peso and some other currencies. Although the evidence is largely anecdotal, trade tensions sparked by the external imbalances of the two countries seem to have contributed to upward pressures on the yen at that time, and as such they may not have been related to configurations of the stance of monetary policies for the two countries.

A natural question concerning the 1990s experience of the United States and Japan is: what could monetary policy have done to improve economic performance? It has been suggested in the case of the United States, for example, that somewhat earlier moves to monetary restraint in 1993 might have tempered the marked swings in bond markets over 1993-1994. But, any undue delay in tightening (which must have been fairly short in any case) has proved to be no more than a minor blemish on a record that, given the robustness of real growth, low unemployment and containment of inflation, stands as highly successful, even after allowing for a certain amount of luck.

The question is much more difficult in Japan's case. The constraint on policy imposed by the banking sector difficulties, the exchange rate misalignment in 1993-1995 and the unwelcome rise in long-term interest rates in 1994 have already been noted. In addition, the Japanese authorities argued that through the Bank of Japan's official discount rate cut of September 1993, policycontrolled nominal short-term interest rates had reached a level low enough to support a gradual 
recovery of economic activity (Figure 5). Conceivably, however, more aggressive easing might have alleviated the continued severity of economic downturn (as argued in the Introduction of the OECD Economic Outlook $54^{6}$, published in December 1993). Although this is by no means clear, the possibility that such policies could have helped, particularly in supporting the nascent recovery that began in late 1993, cannot be ruled out. At the same time, given the underlying conditions behind the weakness in demand and financial sector strains, it seems unlikely that monetary policy alone could have produced more than a fairly limited improvement in macroeconomic performance. ${ }^{7}$ Furthermore, the extent and duration of the downturn were hardly clear to the authorities or outside observers at that point.

\section{Concluding Remarks}

Five broad conclusions emerge from this review of the U.S. and Japanese experiences with monetary policy. First, it is clearly very important that the central bank has sufficient operational autonomy to be able to pursue the goal of price stability, and that its commitment to the goal be credible. The experiences of the United States and Japan illustrate that attainment of this goal rests crucially on consensus among the central bank, political authorities and the public on its overriding importance. In this context, it should be noted that a new legal structure governing the Bank of Japan will come into effect in April 1998, defining price stability as the prime objective of the Bank of Japan's monetary policy and increasing its independence and the transparency of its policy decision process.

Second, monetary policy can be, and has been, successful in the absence of numerical inflation targets or similar devices that help to maintain the needed consensus. Equally, strict adherence to intermediate targets, at least of the sort described in formal economic models, has not proved to be essential to policy success. Indeed, the Bank of Japan has been successful in achieving and maintaining very low inflation or virtual price stability for more than a decade without adhering to intermediate targets. More recently, the United States and many other OECD central banks have also been able to reduce inflation to the lowest levels in nearly two decades without such targets. This is not to deny that the pursuit of intermediate targets can be beneficial if there is a reliable and stable relationship between some intermediate variables on the one hand and nominal GDP and inflation on the other. Nor is an "eclectic" approach to monetary policy to be recommended if it means improvisation without due care to the circumstances in which policy becomes unsustainable, waiting 
too long for data to resolve uncertainties, or reducing the transparency of central bank action and its accountability. The essential requirement under any set of operating procedures is that the monetary authorities be able to identify situations that are likely to increase underlying inflation pressures and, when such situations arise, that they act decisively in adjusting their operating instruments with the understanding and support of the general public -- see also Shigehara, 1996(a).

A third conclusion is that monetary policy cannot try to, or be asked to, accomplish too many tasks if it is to be consistently successful in achieving its ultimate goal of price stability. This is not to deny that monetary policy can contribute to economic stabilisation within the medium-term framework of price stability. But, in Japan, the entanglement of external objectives with domestic considerations impaired economic performance at key points during the recent decade, even if not decisively. The comparative freedom of U.S. authorities to focus on domestic objectives has made an important contribution to its relatively successful performance during this period. Internationally coordinated discretionary use of monetary policy for the sake of exchange rate stabilization can run the risk of aggravating domestic economic instability, in particular when fiscal policies are misaligned or, more generally, when cyclical positions diverge significantly across countries. Further improvements in multilateral surveillance on macroeconomic policy at international fora, such as those provided by the OECD and the IMF, involving both government and central bank officials could contribute to better monetary policy making, even though decisions about monetary and fiscal policy can be separated technically. ${ }^{8}$

A fourth conclusion is that the soundness of the banking system is crucial in ensuring effective monetary policy. Moreover, the existence of well-functioning capital markets can enhance the effectiveness of the market-oriented conduct of monetary policy. There are reasons for the monetary authorities to be concerned about prudential policies regarding the entire financial system, even if some aspects of these policies do not directly fall under their responsibilities.

Fifth and finally, academic and other scholarly analyses, theoretical as well as empirical, can help the monetary authorities in improving the sophistication and skill of policy formulation and implementation. It is doubtful that policy would have been as successful as it has been over the last decade, had monetary authorities not absorbed the basic monetarist message that there is no permanent trade-off between inflation and unemployment, that money does matter critically to inflation control, and that expectations are crucial in shaping the responses of financial markets and the real economy to policy actions. The most persuasive evidence for these and other elements of the "intellectual tool- 
kit" used by the monetary authorities comes from historical experience, but objective and rigorous analysis has been essential in defining and clarifying these lessons and establishing consensus on their validity. Of course, economic models cannot adequately capture the full range of uncertainties and risks with which policy practitioners must contend. Actual monetary policy, therefore, is rarely likely to fit any theoretical paradigm especially well, and is likely always to look a bit untidy by theoretical standards. Nevertheless, practitioners cannot throw away the tool box simply because no single constituent will serve ideally for all occasions. Monetary policy remains an art, but one that has to draw on the wisdom provided by scholars as well as heed the lessons from its own past mistakes. 
(Standard deviation of four quarter growth rates)

\begin{tabular}{|l|c|c|c|c|}
\hline & \multicolumn{2}{|c|}{$1972-84$} & \multicolumn{2}{c|}{$1985-96$} \\
\hline Component/Country & US Japan & US & Japan \\
\hline Real GDP & 3.21 & 2.51 & 1.38 & 2.00 \\
\hline Personal consumption & 2.47 & 2.82 & 1.36 & 1.52 \\
\hline Business investment & 8.77 & 6.87 & 5.42 & 8.12 \\
\hline Housing investment & 20.43 & 10.52 & 9.10 & 10.43 \\
\hline All other* & 5.56 & 5.01 & 2.89 & 3.30 \\
\hline
\end{tabular}

* net exports, government spending, and inventories 
Table 2

\section{Trade Openness in Selected Countries}

(In per cent of GDP in 1995)

\begin{tabular}{|c|c|c|c|c|}
\hline & \multicolumn{2}{|c|}{ Exports } & \multicolumn{2}{|c|}{ Imports } \\
\hline & Total & $\begin{array}{l}\text { with the } \\
\text { prospective } \\
\text { euro area* }\end{array}$ & Total & $\begin{array}{l}\text { from the } \\
\text { prospective } \\
\text { euro area* }\end{array}$ \\
\hline United States & 11.3 & 1.7 & 12.4 & 1.6 \\
\hline Japan & 9.4 & 1.1 & 7.9 & 0.9 \\
\hline Germany & 23.6 & 10.4 & 22.9 & 10.1 \\
\hline France & 23.5 & 12.3 & 21.2 & 11.3 \\
\hline Italy & 25.1 & 11.8 & 22.2 & 11.4 \\
\hline Austria & 38.6 & 22.9 & 39.0 & 26.0 \\
\hline Belgium & 67.3 & 43.3 & 62.7 & 39.8 \\
\hline Finland & 37.7 & 12.3 & 29.3 & 10.1 \\
\hline Ireland & 79.8 & 34.4 & 68.2 & 12.8 \\
\hline Netherlands & 53.3 & 33.1 & 46.6 & 21.7 \\
\hline Portugal & 33.3 & 21.6 & 40.5 & 26.6 \\
\hline Spain & 24.0 & 14.8 & 23.9 & 13.2 \\
\hline Canada & 37.4 & 1.7 & 35.0 & 2.4 \\
\hline Korea & 33.1 & 2.0 & 34.1 & 2.4 \\
\hline Australia & 19.6 & 1.4 & 20.8 & 3.4 \\
\hline
\end{tabular}

* The prospective euro area is defined to consist of the countries planning

to participate in European Economic and Monetary Union from 1 January 1999: Germany, France, Italy, Austria, Belgium, Luxembourg, Finland, Ireland, Netherlands, Portugal, Spain. 
Fig. 1

\section{Performance Indicators}
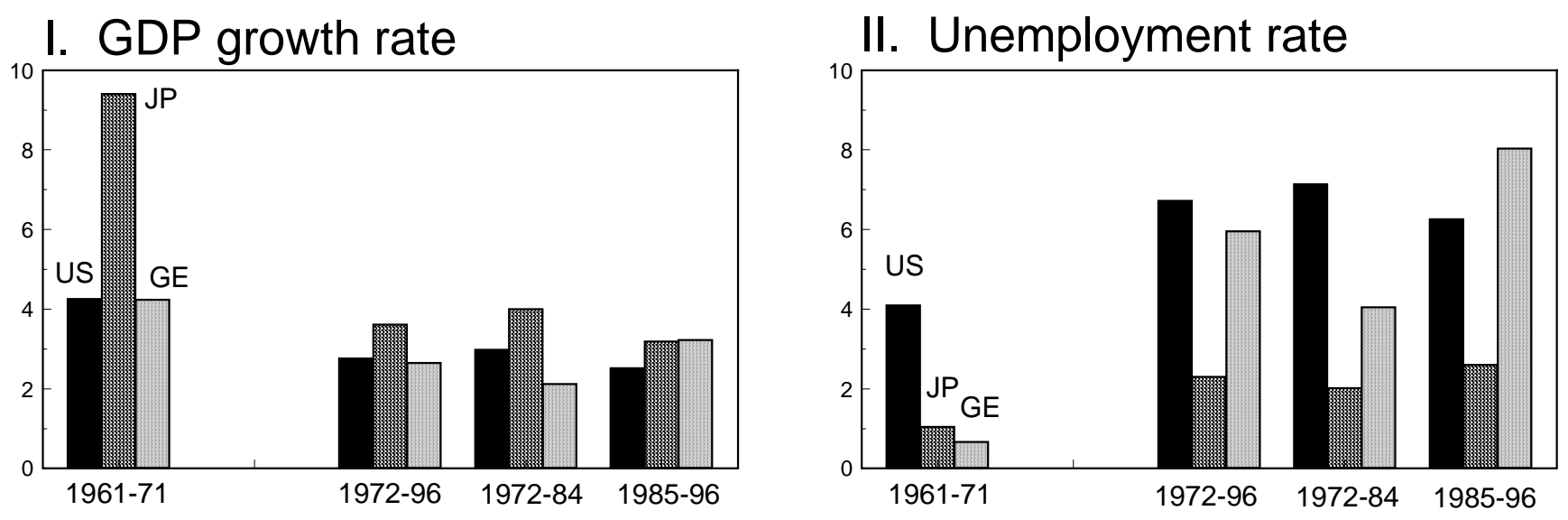

IIIA. Inflation, consumer prices
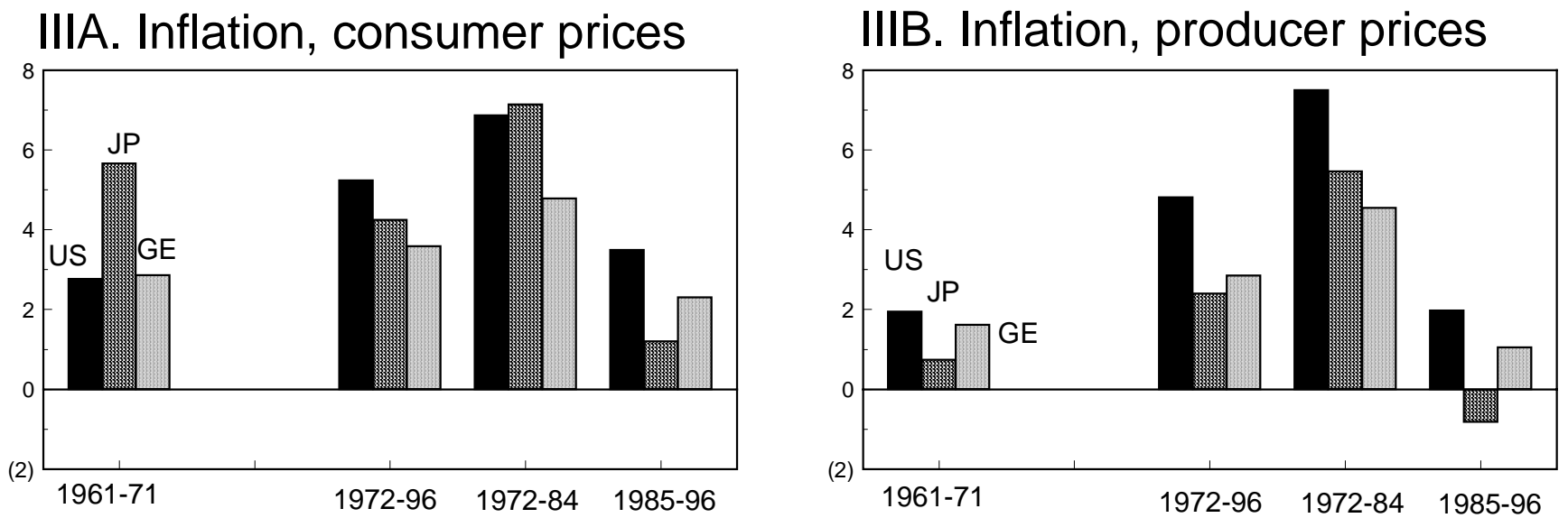

Note: Figures are annualised averages over the periods indicated. 
Fig. 1 (continued)

\section{Performance Indicators}
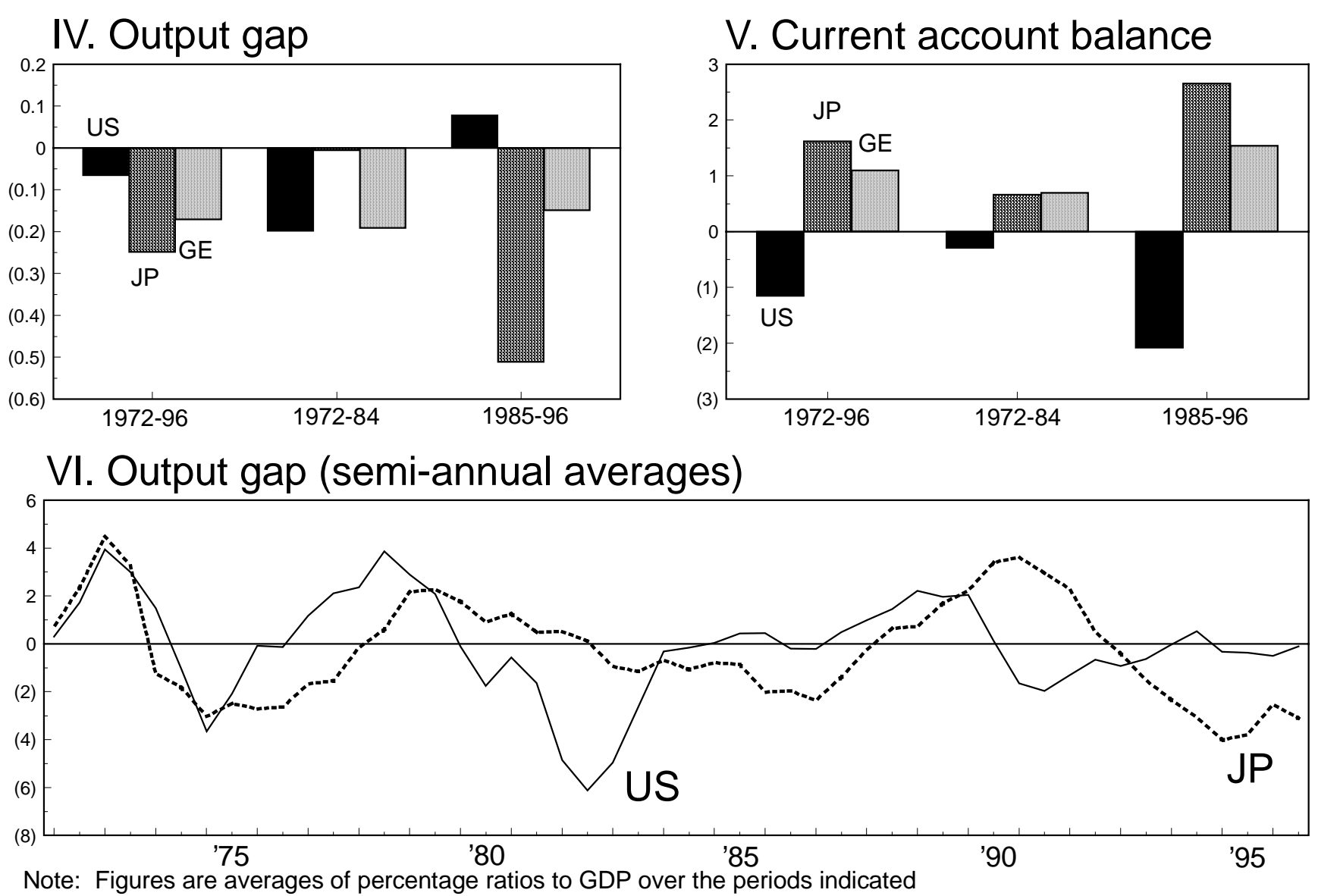
Fig. 2

\section{Money Aggregates}

\section{US}

Growth rate *

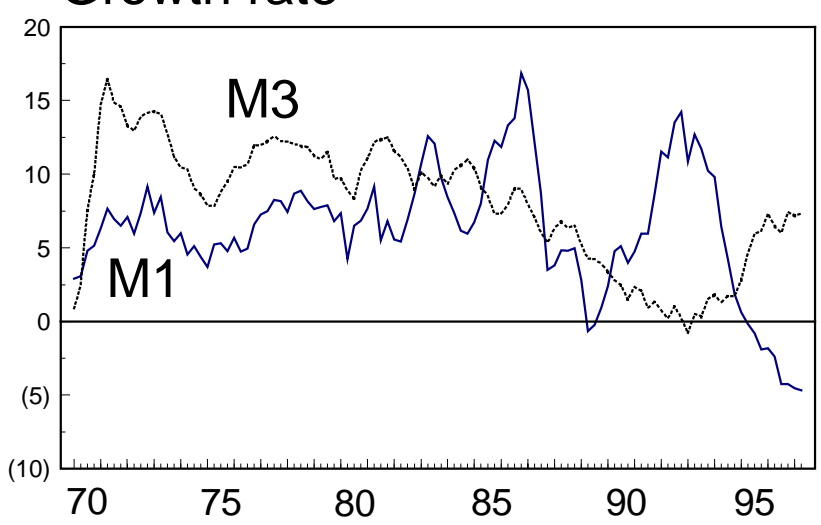

Japan

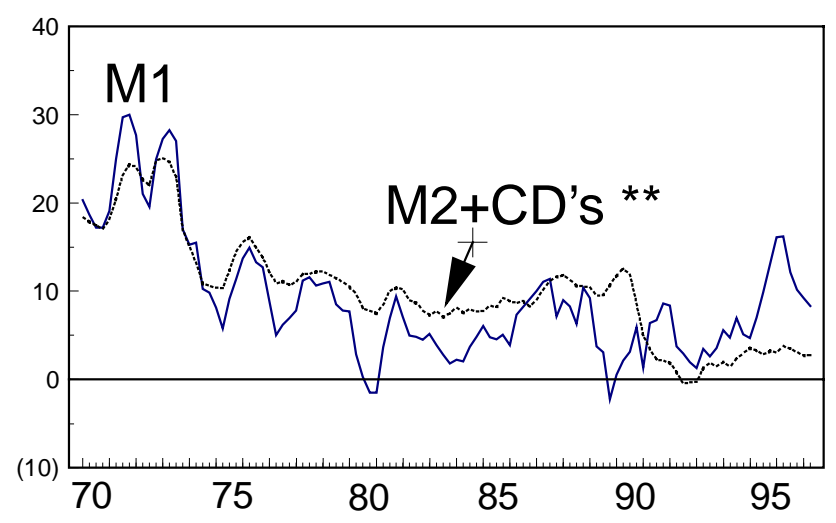

nverse of velocity (M/GDP)

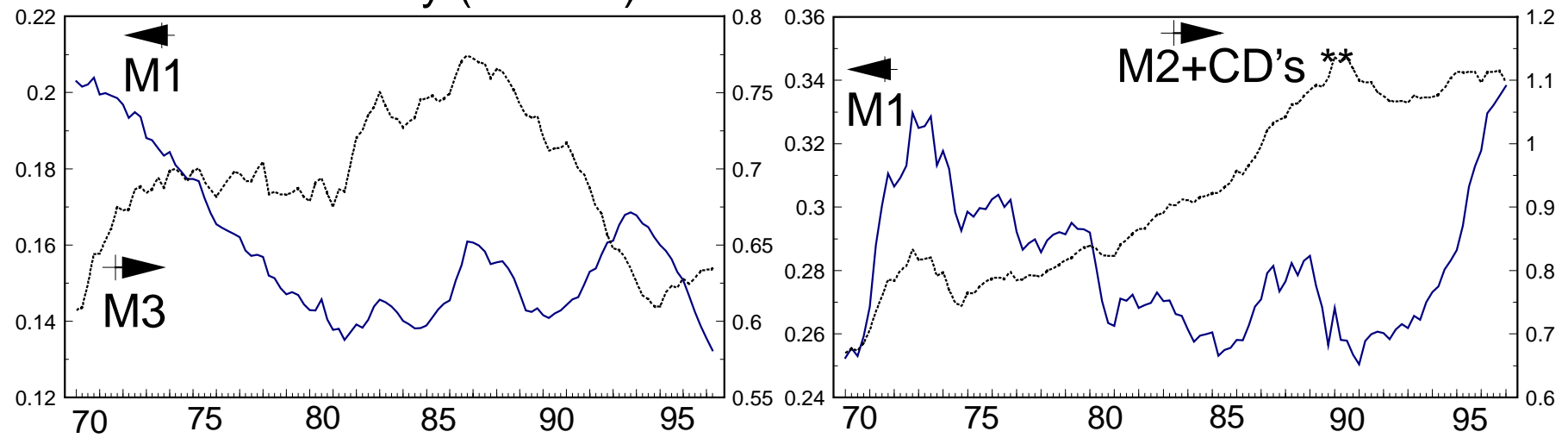

* The growth rate is measured as the percentage change over the corresponding quarter of the previous year.

** Growth prior to 1980, and the velocity data prior to 1979, include M2 only as CD's were not available until 1979. 
Fig. 3

\section{Exchange Rates}

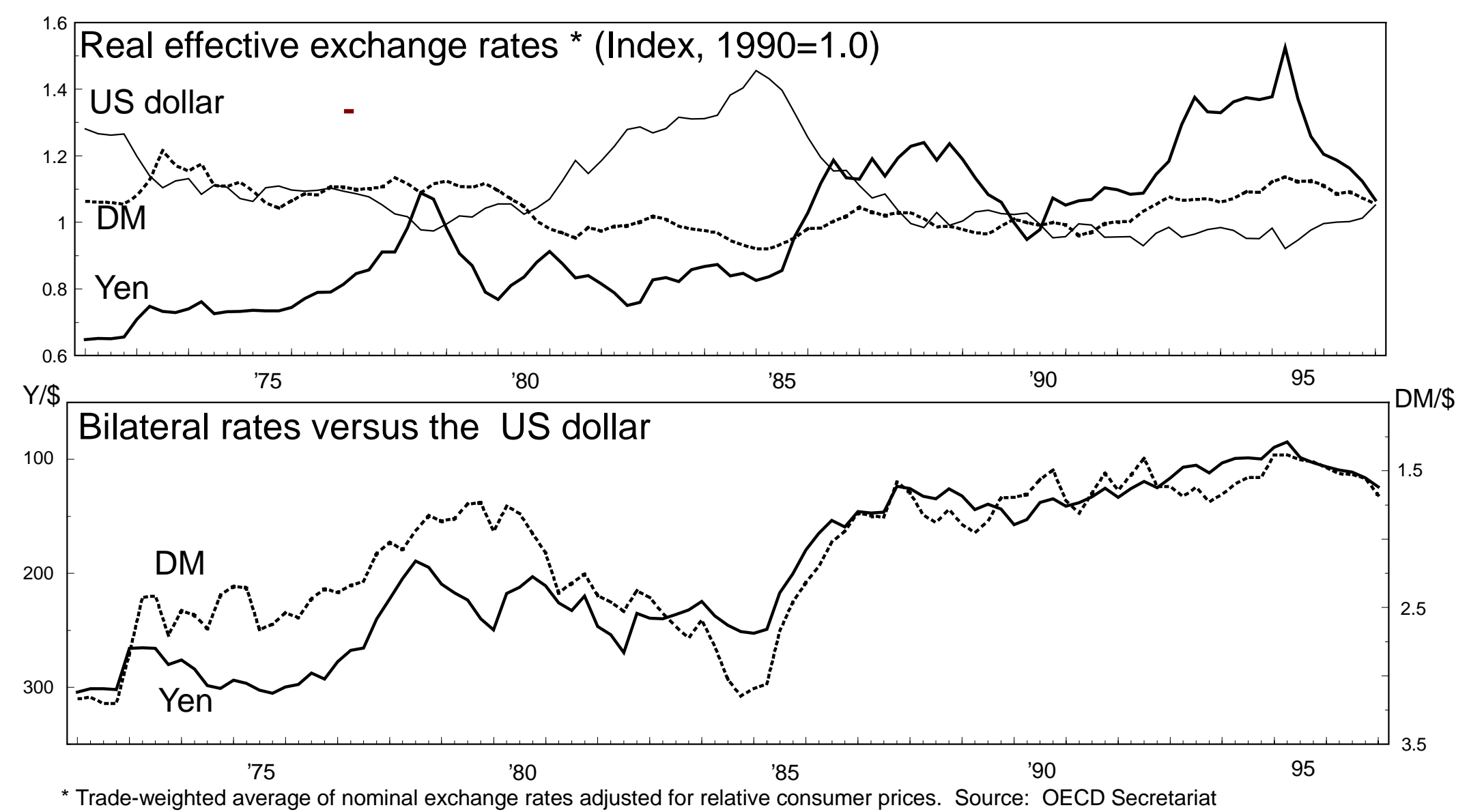


Fig. 4

\section{Fiscal Impulse}
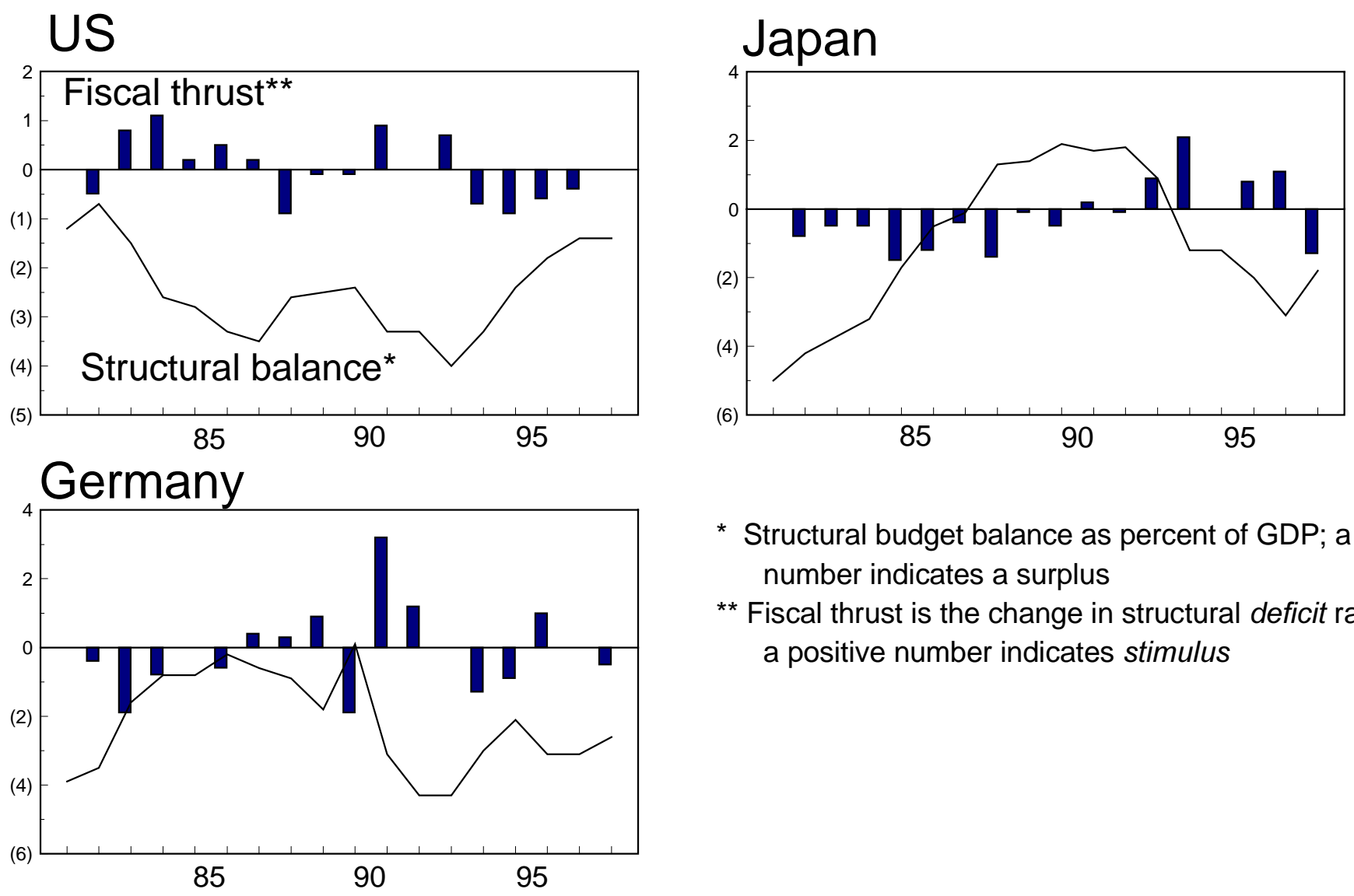

* Structural budget balance as percent of GDP; a positive number indicates a surplus

** Fiscal thrust is the change in structural deficit ratio to GDP: a positive number indicates stimulus 
Fig. 5

\section{Policy Interest Rate in Japan}
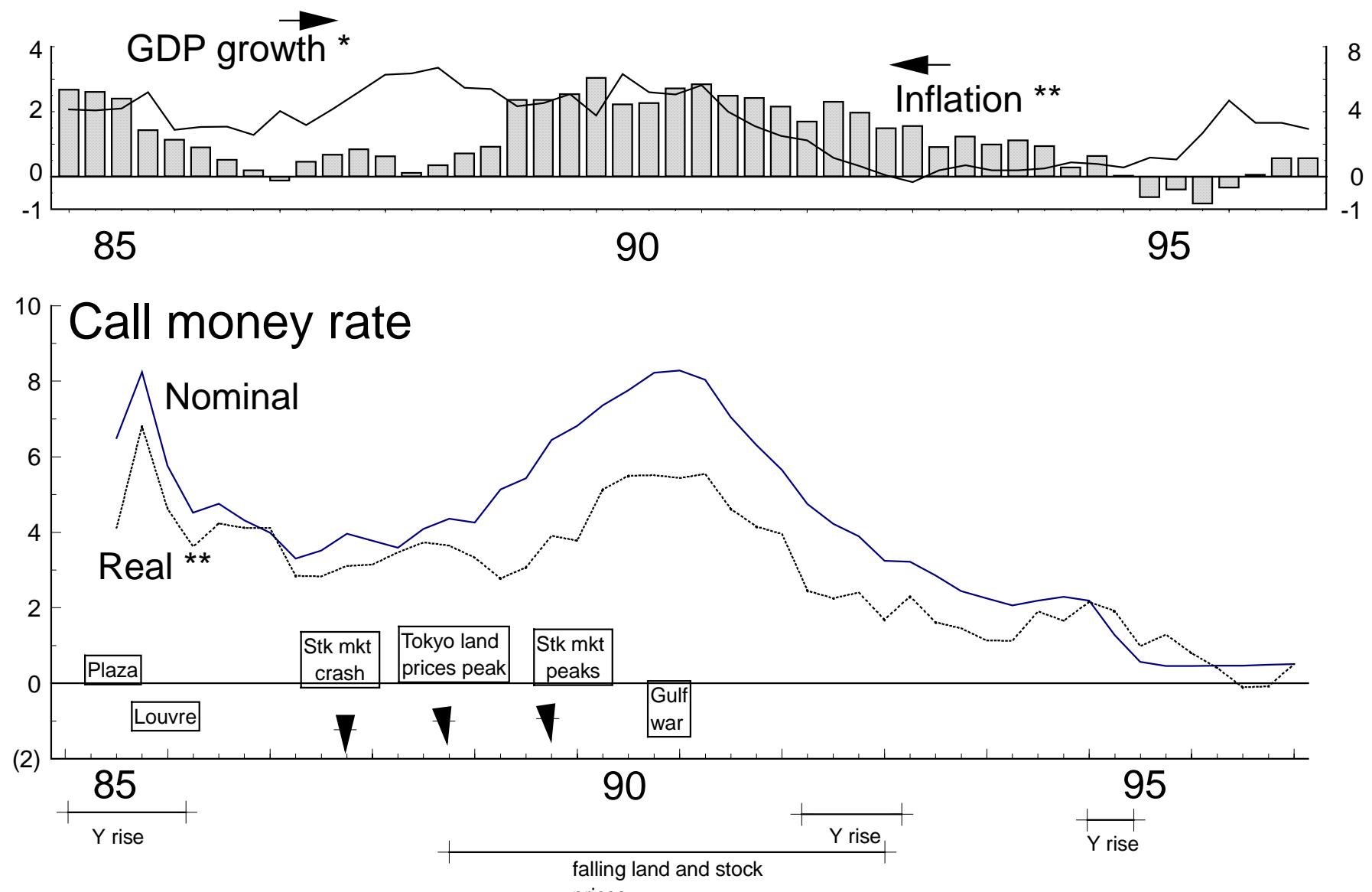

prices

* Growth is measured as the per cent change over the corresponding quarter of the previous year.

** Inflation is measured by the consumption component of the GDP deflator; the real interest rate is the nominal rate less the inflation rate over the prior four quarters. 
Fig. 6

\section{Policy Interest Rate in the U.S.}
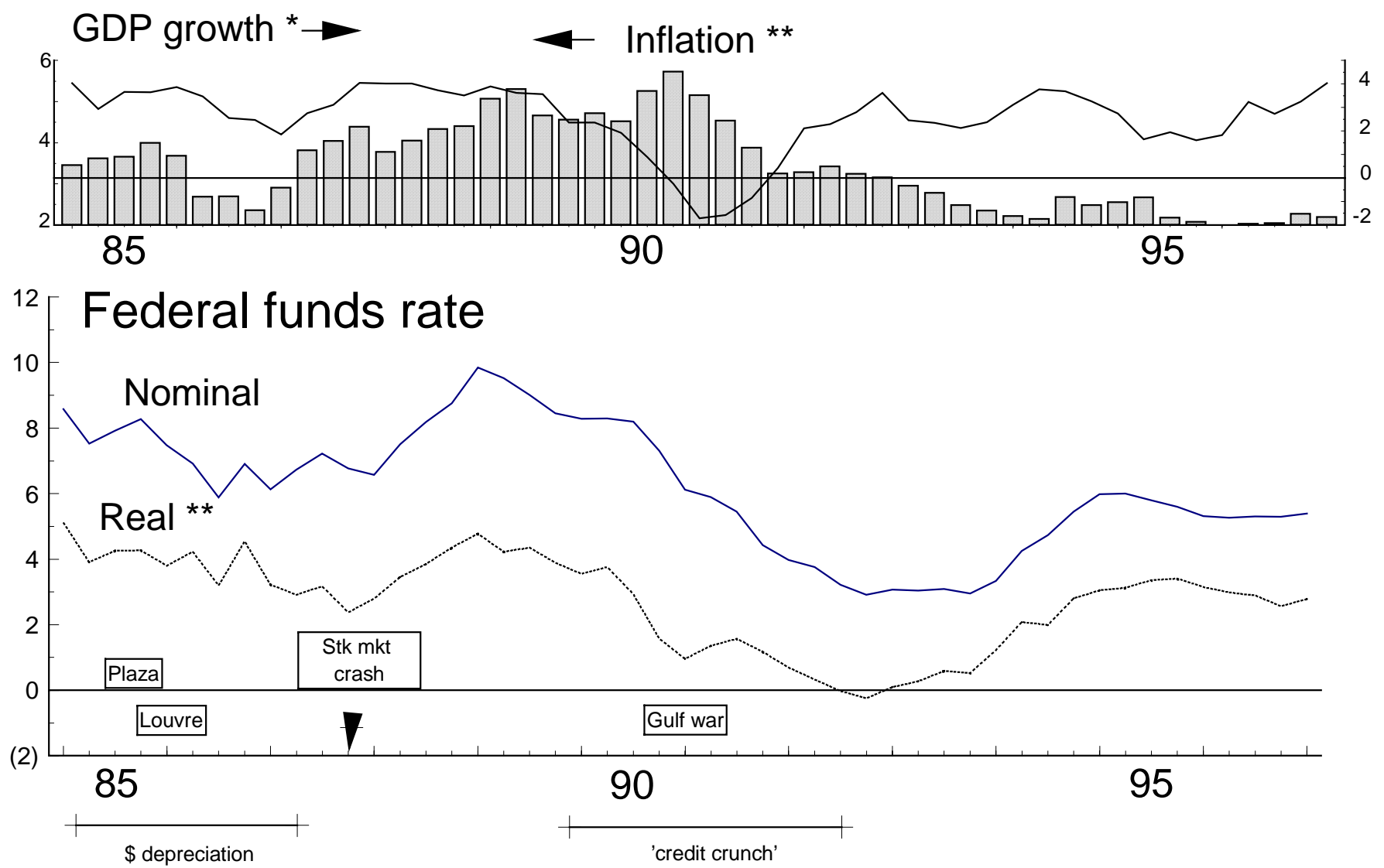

* Growth is measured as the per cent change over the corresponding quarter of the previous year.

** Inflation is measured by the consumption component of the GDP deflator; the real interest rate is the nominal rate less the inflation rate over the prior four quarters. 
Fig. 7

\section{Stock Prices}

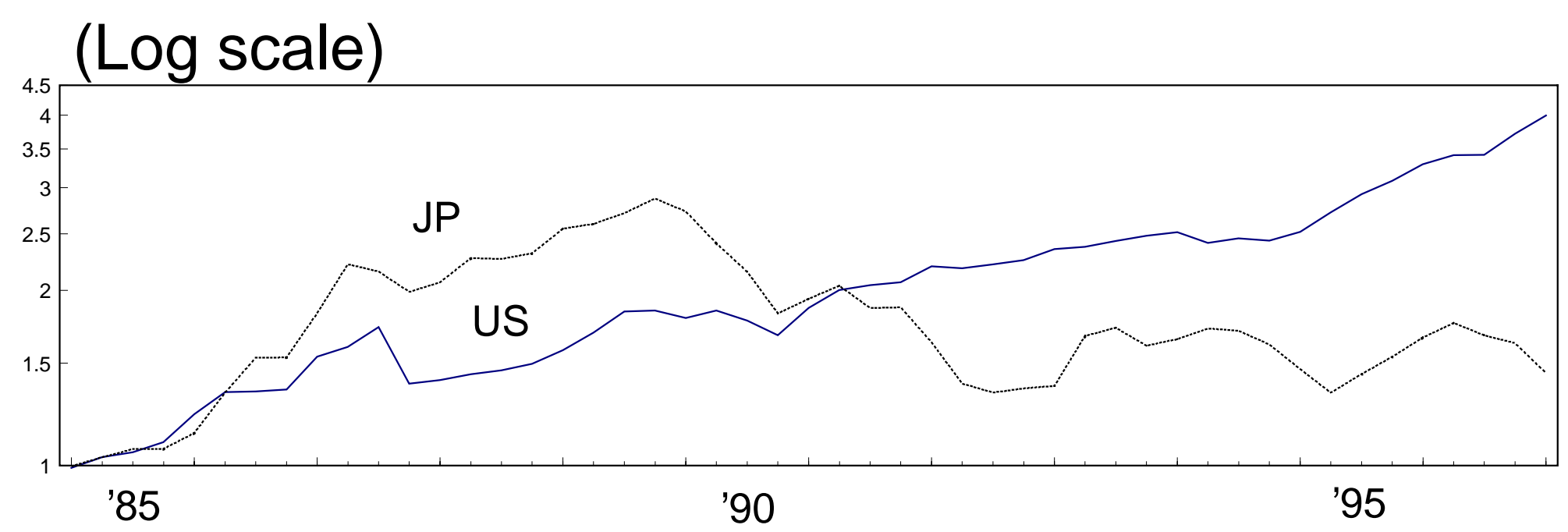

Notes: US: composite index; Japan: TSE composite. Last date: 1997Q1 
Fig. 8

\section{Japanese Land Prices}

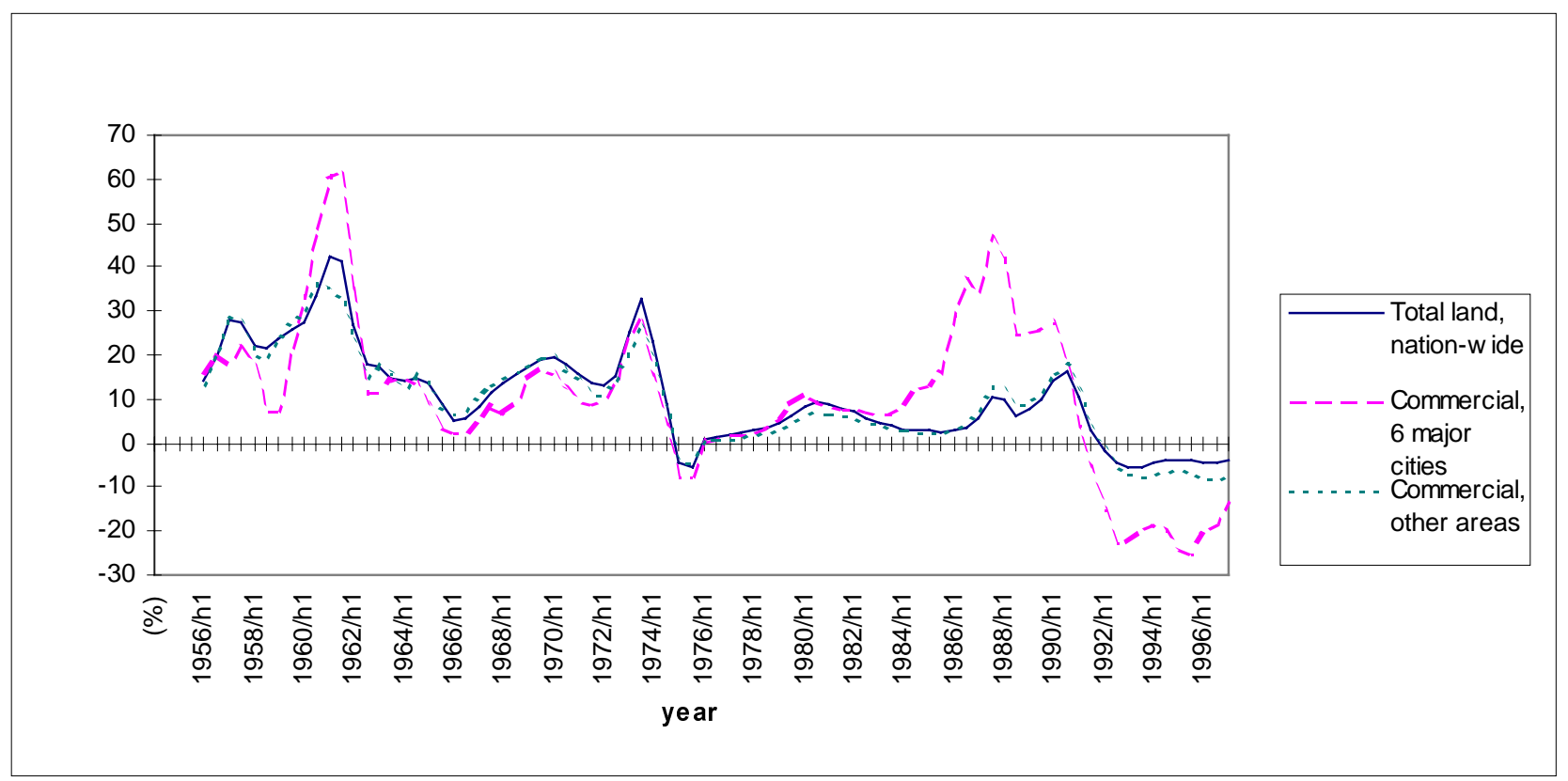

Note: figures are year-to-year percentage changes 
Fig. 9

\section{Bank Loans and Spreads}

Growth in bank lending *

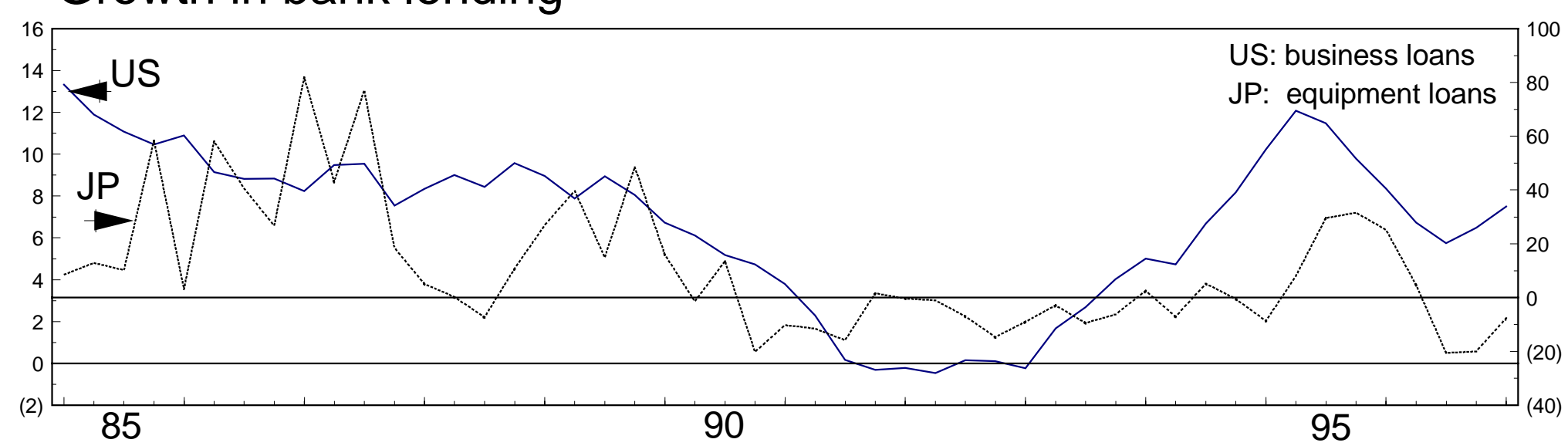

Japanese bank loan rate spreads

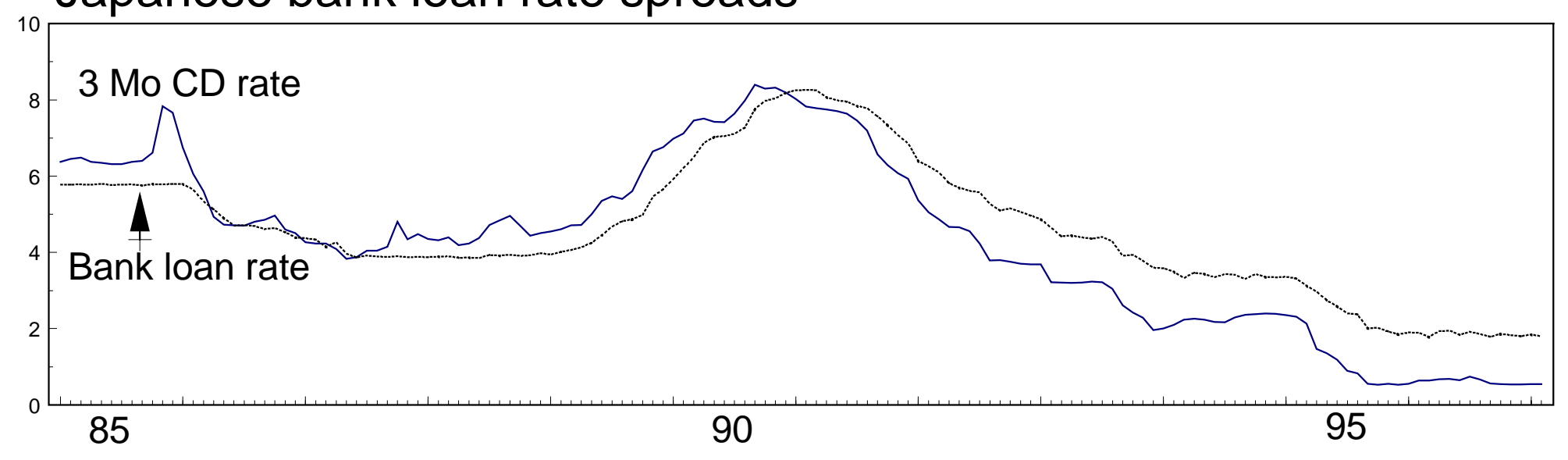

* Growth is measured as the per cent change over the corresponding quarter of the previous year. 
Fig.10

\section{Long Term Interest Rates}

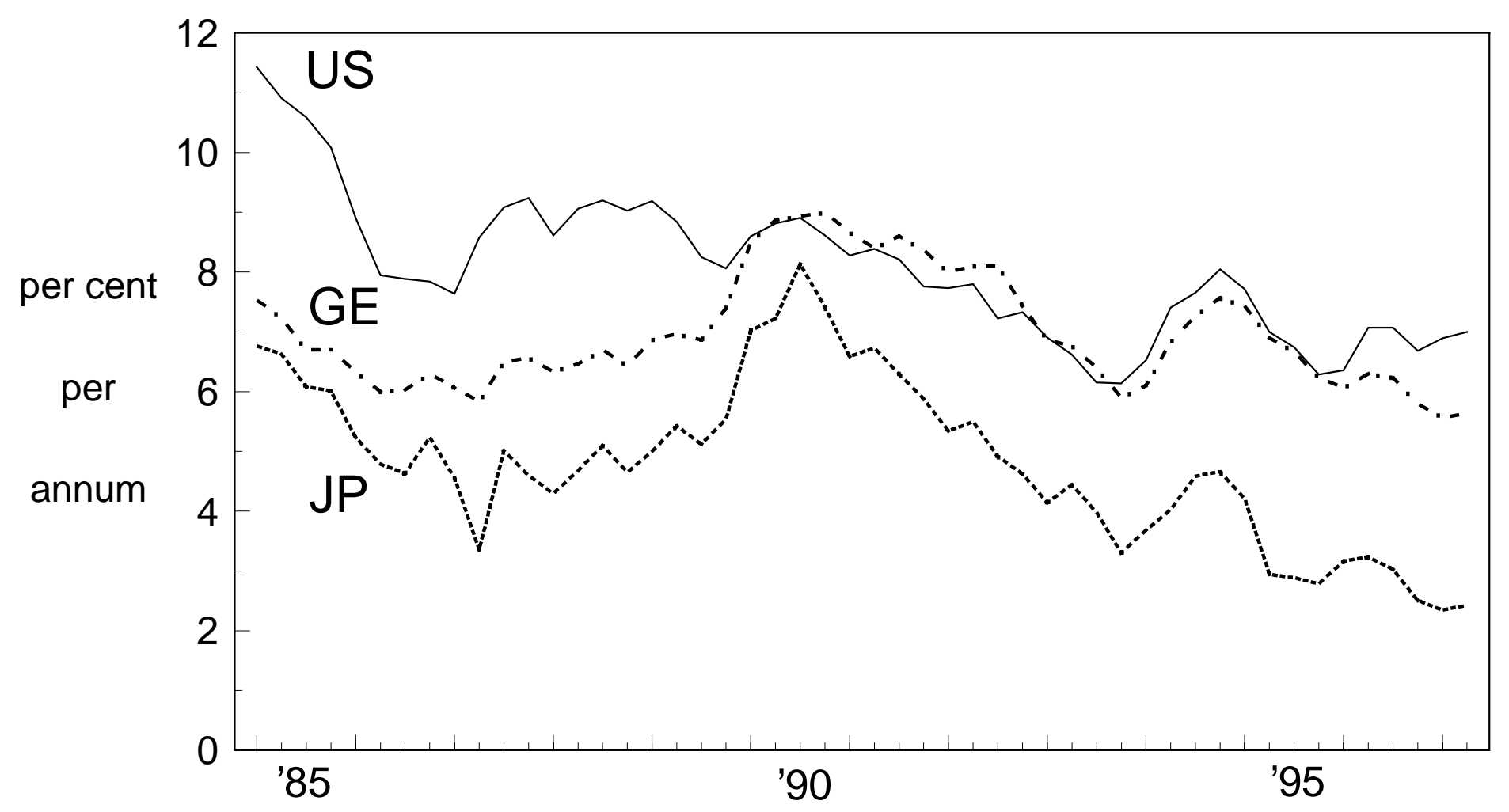

Notes: US rate is a composite yield on 10 year federal government bonds; Japanese rate is the yield on 10 year central government bonds; German rate is an average yield of 7-15 year outstanding public sector bonds. 


\section{References}

AKHTAR, M. Akbar, "The Causes and Consequences of the 1989-1992 Credit Slowdown”, in the Quarterly Review of the Federal Reserve Bank of New York, Winter, 1993-94.

ALCHIAN, A., KLEIN, B. “On a Current Measure of Inflation”, Journal of Money, Credit and Banking, Vol. 5, Nov. 1975.

BANK OF ENGLAND, "Monetary Policy in the Second Half of the 1980s”, Bank of England Quarterly Bulletin, May 1990, pp. 215-220.

BOARD OF GOVERNORS OF THE FEDERAL RESERVE SYSTEM, Annual Report, issues for 1985 and 1987.

FRIEDMAN, Benjamin M., “The Rise and Fall of Money Growth Targets as Guidelines for U.S. Monetary Policy” in Kuroda, I. (ed.) Towards More Effective Monetary Policy, Macmillan Press, 1997.

FRIEDMAN, Benjamin M., "The Role of Judgment and Discretion in the Conduct of Monetary Policy: Consequences of Changing Financial Markets", in Changing Capital Markets: Implications for Monetary Policy, The Federal Reserve Bank of Kansas City, 1993.

FRIEDMAN, Milton, “The Role of Monetary Policy”, American Economic Review, 58, 1968.

FRIEDMAN, Milton, "Monetarism in Rhetoric and in Practice" in Ando, Albert et al (eds.), Monetary Policy in Our Times, MIT Press, 1985.

GREENSPAN, Alan, Remarks at 55th Annual Dinner of the Tax Foundation, New York, 18 November 1992, mimeo.

HAMADA, Kôichi and HAYASHI, Fumio, “Monetary Policy in Postwar Japan” in Ando, Albert et al (eds.), Monetary Policy in Our Times, MIT Press, 1985.

HUTCHISON, Michael, “Asset Price Fluctuations in Japan: What Role for Monetary Policy”, Bank of Japan Monetary and Economic Studies, Vol. 11, No. 1 (July 1993).

KEECH, William R. and MORRIS, Irwin L., “Appointments, Presidential Power, and the Federal Reserve”, Journal of Macroeconomics, Spring 1997, Vol. 19, No. 2, pp. 253-267. Louisiana State University Press, 1997. 
KOHN, Donald, Commentary: "The Role of Judgment and Discretion in the Conduct of Monetary Policy", in Changing Capital Markets: Implications for Monetary Policy, Federal Reserve Bank of Kansas City, 1993.

MATSUSHITA, Yasuo, “A New framework of Monetary Policy under the New Bank of Japan Law”, forthcoming, Bank of Japan Quarterly Bulletin, November 1997.

MELTZER, Alan, Commentary: "The Role of Judgment and Discretion in the Conduct of Monetary Policy", in Changing Capital Markets: Implications for Monetary Policy, Federal Reserve Bank of Kansas City, 1993.

NAKAGAWA, Yukitsugu, “Taikenteki Kinyûseisaku-ron” (in Japanese), Nihon Keizai Shimbunsha, 1981.

OECD Economic Outlook 54, December 1993, pp. vii - xiv.

OECD, Economic Surveys, Japan, for the years 1993, 1994, 1995 and 1996.

PHELPS, Edmund, “Money-Wage Dynamics and Labour Market Equilibrium”, Journal of Political Economy, 76, August 1968.

PAULS, Diane B.,"U.S. Exchange Rate Policy and its Relation to Monetary Policy”, in The Orientation of Monetary Policy and the Monetary Policy Decision Process., Bank for International Settlements, 1991.

POOLE, William "Exchange rate management and monetary policy mismanagement: A study of Germany, Japan, United Kingdom and United States after Plaza", Carnegie-Rochester Conference Series on Public Policy 36; 1990, pp. 59, 63.

PRELL, Michael.J., "What does the Fed Look At?" in The Orientation of Monetary Policy and the Monetary Policy Decision Process, Bank for International Settlements, 1991

SHIGEHARA, Kumiharu, “Absorption of the Two Oil Shocks: the Japanese Case”, European Economic Review, No. $18,1982$.

SHIGEHARA, Kumiharu, "Japan's Experience with Monetary Policy and Financial Liberalisation" in Monetary Policy and Market Operations, Reserve Bank of Australia, Sydney, 1990.

SHIGEHARA, Kumiharu, “The Options Regarding the Concept of a Monetary Policy Strategy”, in Deutsche Bundesbank (ed.) Monetary Policy Strategies in Europe, Verlag Vahlen, 1996(a).

SHIGEHARA, Kumiharu, "Multilateral Surveillance: What the OECD Can Offer”, OECD, 1996(b). 
SUZUKI, Yoshio, "Monetary Policy in Japan: Transmission Mechanism and Effectiveness”, Bank of Japan, Monetary and Economic Studies, Vol. 2, No. 2, 1984.

SUZUKI, Yoshio, The Japanese Financial System, Oxford Press, 1987.

TAYLOR, John, "Differences in Economic Fluctuations in Japan and the United States: the Role of Nominal Rigidities", Journal of the Japanese and International Studies, 3, 1989.

UEDA, Kazuo, “Japanese Monetary Policy from 1970 to 1990: Rules or Discretion?" in Shigehara, K. (ed.) Price Stabilisation in the 1990s, Macmillan Press, 1993.

UEDA, Kazuo, "Japanese Monetary Policy, Rules or Discretion? A Reconsideration”, in Kuroda, I. (ed.) Towards More Effective Monetary Policy, Macmillan Press, 1997.

YOSHIKAWA, Hiroshi, and OHARA, Hidetaka, "Heisei” Keiki - Fukyô to Setsubitôshi (in Japanese). IMES discussion paper 97-J-2, 1997. 
1 For example, the Governor of the Bank of England in 1990 acknowledged that policy mistakes and forcasting errors had played a part in the resurgence of inflation in the United Kingdom, see Bank of England Quarterly Bulletin, May 1990, pp. 215-220.

2 See The Economy in 1985 and The Economy in 1996 in the Annual Reports of the Federal Reserve for 1985 and 1997, respectively, as well as the Federal Reserve Chairman's (Humphrey Hawkins) testimonies to the U.S. Congress and the minutes of the FOMC meetings contained in those volumes. The records of these deliberations indicate that policy-makers also gave careful consideration as to how U.S. monetary policy actions in conjunction with policies of U.S. partners might affect perceptions of foreign exchange market participants in these instances.

3 See the FOMC minutes for the latter half of 1986 and 1987 (March, May and July in particular). The authorities were acutely aware that policy had been quite accommodative for much of 1986 . Concerns about the potential inflationary effects of the dollar's decline seem to have been an important factor in "catalysing" sentiment to begin to firm.

${ }^{4}$ For example, the nearly 23/4-fold increase in Japanese stock prices between 1985 and their peak in 1989 may itself seem excessive, but it is interesting to note that U.S. prices have increased more than two-fold since 1992, after having already increased substantially from 1982 to then. Admittedly, the price earnings ratio reached in the Japanese market in the late 1980s were very high in comparison with those other countries, even after accounting for share cross-holdings and other accounting differences. However, Japanese price-earnings ratios have been very high for nearly two decades, and are still well above those in the United States.

5 The Federal Funds rate was reduced to 3 per cent in September 1992, driving down real short-term money market rates to almost zero.

6 The OECD Economic Outlook 54 prepared by the Economics Department under the direction of Kumiharu Shigehara in late 1993 argued that monetary conditions in Japan were tighter than the level of nominal interest rates might imply, and that further action would be needed for effective monetary easing. The Bank of Japan's official discount rate that had been kept unchanged at 1.75 per cent since September 1993 was brought down to 1.0 per cent in April 1995 and to 0.5 per cent in September 1995.

7 See the OECD Economic Surveys on Japan for 1993, 1994, 1995 and 1996 regarding the role of expansionary fiscal policies adopted by the Japanese government.

8 In light of the experience of monetary policies in the United States and Japan, where labour markets are relatively flexible (see Shigehara, 1982; Taylor, 1989), this paper does not discuss the implications of wage rigidities for the conduct of monetary policy and the cost of disinflation. This issue is more relevant in many European countries where such rigidities have increased over the past two decades and raised the cost of disinflation (Figure 1). This illustrates the importance of multilateral surveillance on the interaction between macro and structural policies -- see Shigehara, 1996(b). 